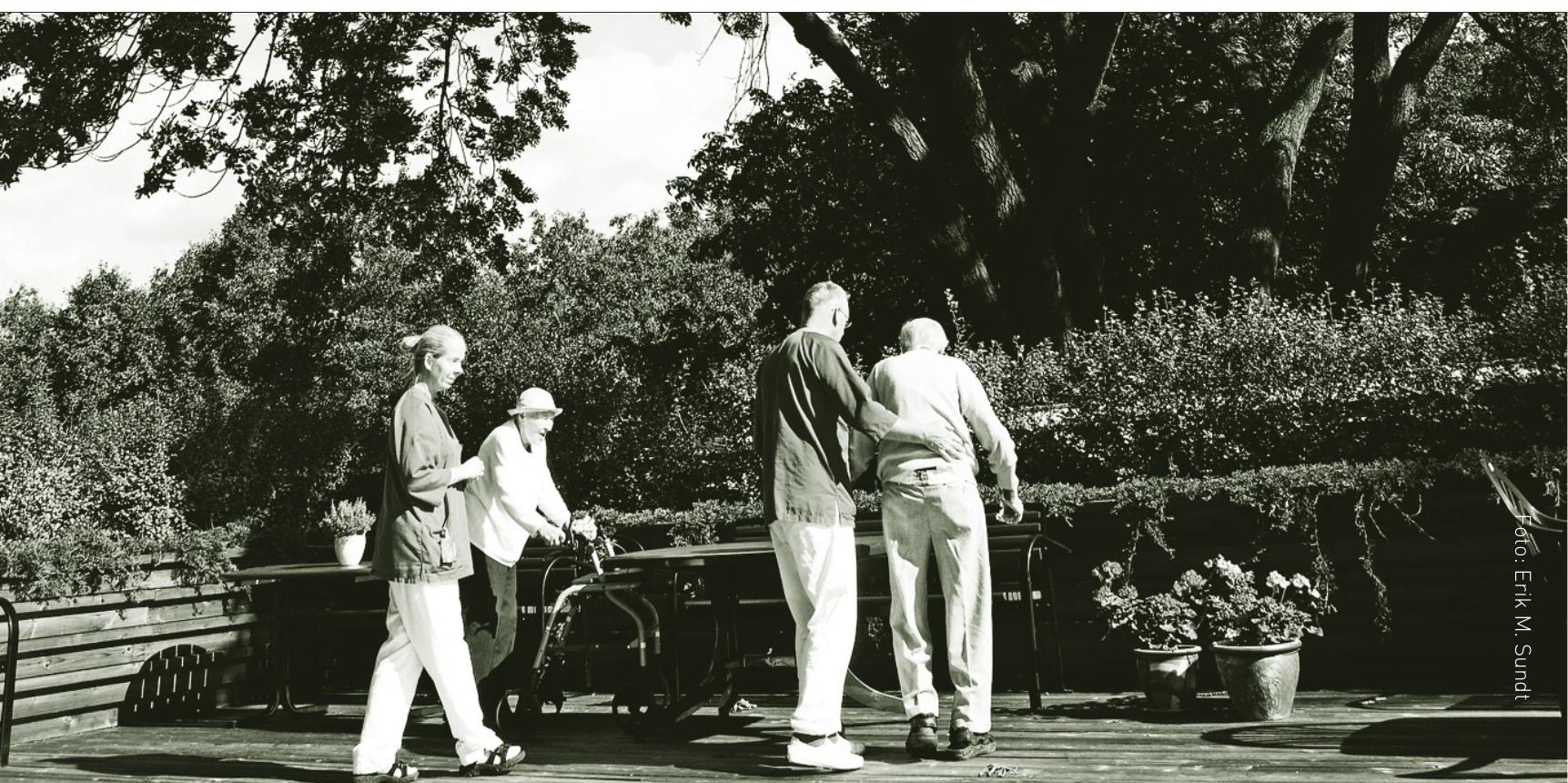

Studiens bakgrunn: Myndighetene oppfordrer til forskning, fagutvikling og veiledning vedrørende miljøbehandling i demensomsorgen. Det finnes cirka 66.000 personer med demens i Norge i dag og tallet er $\emptyset$ kende. Symtomer av atferdsmessige karakter er vanlig og kan ofte resultere i utfordrende atferd. Denne atferden kan føre til vanskelige situasjoner mellom pleier og pasient.

Hensikt: Studien unders økte hvilken betydning Marte meo-veiledning (MM) har hatt for personalets opplevelse av mestring i vanske- lige stellesituasjoner og hvordan personalet har vurdert verdien av metoden.

Metode: Det er benyttet et kvalitativ design med fokusgruppeintervju som datainnsamlingsmetode.

Resultater: Resultatene av studien viser at MM kan ha positiv innvirkning på personalets mestringsf $\varnothing$ lelse. Alle informantene opplevde at metoden kunne redusere opplevelsen av stress i vanskelige stellesituasjoner. Å se seg selv på film, sammen med kolleger, og få positive tilbakemeldinger økte tryggheten og samarbeidet blant personalet. Filmveiledningen opplevdes som et tydelig og sterkt medium som førte til økt refleksjon og bevisstgjøring av personalet. Imidlertid ser vi at MM kan ha ulik betydning for ulike arbeidssteder.

Konklusjon: Hvert arbeidssted bør vurdere sitt eget behov for veiledning og kompetanseoppbygging for å kunne tilpasse metoder og tilnærminger. MM kan være en nyttig metode ved særskilte samspillsutfordringer.
How the Marte-meo method affects the personnels' perception of coping in dementia care

Background: The Government encourages research, development and guidance concerning environmental therapy within dementia care. There are approximately 66,000 people in Norway who suffer from dementia and the numbers are increasing. Behavioural symptoms of psychological and psychiatric character are common and might result in challenging conduct which may create difficult situations between caregiver and patient.

Objectives: The aim of this article was to study of the influence of the Marte-meo method (MM) on the caregivers' perception of coping in difficult situations and how the caregivers have assessed the significance of the method.

Methods: A qualitative design is used with focus group interviews for data gathering.

Results: The results show that MM might have a positive influence on the caregivers' perceived coping methods. All informants experienced reduced stress in difficult situations. A positive retrospective video-based assessment from actual situations enhanced the collegiate collaboration and the feeling of security. MM was generally accepted as positive by the caregivers and as a powerful method for increased consciousness and reflection.

Conclusions: MM might have a varying influence on different workplaces. Each workplace should assess its own requirement for guidance and needed competence in order to adapt both methods and approaches. MM might be advantageous if used on special challenges regarding interaction.

Key words: Focus group, coping supervision, dementia 


\section{" Hvordan påvirker Marte meo- veiledning personalets opplevelse av egen mestring i demensomsorgen?}

Forfattere: Anette Hansen og Siri Ytrehus

\section{NøKKELORD \\ - Fokusgrupper \\ - Mestring \\ - Veiledning \\ - Demens}

\section{BAKGRUNN}

I Norge finnes det cirka 66.000 personer med demens og tallet er sterkt økende (1). Myndighetene oppfordrer til forskning og fagutvikling innenfor demensområdet. Viktigheten av kompetanseheving og veiledning av personalet vektlegges (1). Atferdsmessige symptomer er så vanlig at det må anses som en del av demenssyndromet $(2,3)$. I tillegg til psykososiale forhold kan blant annet miljø påvirke utfordrende atferd. At pasienten ikke forstår situasjonen, blir engstelig eller ikke klarer å kommunisere sine tanker og behov er noen av årsakene som kan føre til både verbal- og fysisk utagering (6).

Det kan oppstå vanskelige stellesituasjoner med utfordrende atferd i samhandlingen mellom pleier og pasient.
Disse situasjonene kan oppfattes svært krevende for begge parter $(2,4,5)$. $\AA$ jobbe innen demensomsorgen kan være belastende, spesielt med hensyn til situasjoner ansatte opplever ikke å mestre. Personalet reagerer både følelsesmessig og atferdsmessig ulikt og takler derfor ulike hendelser forskjellig (6). Det blir viktig å ivareta personalet og sørge for at de har tilstrekkelig kunnskap om og forståelse for pasientens behov (6). I demensomsorgen brukes i dag ulike metoder for observering og veiledning blant annet Dementia Care Mapping (DMC) $(7,8)$ og Marte meo-veiledning (MM) $(6,9)$.

\section{MESTRING OG VEILEDNING}

Mestringsbegrepet benyttes innen ulike disipliner og er et omfattende og mangfoldig begrep, som kan defineres på mange ulike måter. Lazarus og Folkman (10) legger vekt på en prosessorientert definisjon av mestring og de gjør et skille mellom selve handlingen og konsekvenser av denne.

Mestring defineres ifølge Lazarus og Folkman som: «Dynamisk endring av kognitive prosesser og oppførsel for å møte eksterne krav og/eller nå personlige målsettinger som vurderes av den enkelte som belastende eller vanskelig» (fritt oversatt etter 10, s. 141).

Denne definisjonen gir en god basis for forståelse av mestring. Definisjonen henspiller på hva individer gjør og tenker og ikke hva individet er. Det er denne mestringsforståelsen som ligger til grunn for studien denne artikkelen bygger på.

Innen mestringsteori er egne forventninger til mestring sentralt. Det er vanlig å hevde at redsel og usikkerhet får innvirkning på mestring. Mestringsfor-

Hva tilfører denne artikkelen?

Studien viser at Marte meo-metoden kan bidra til at helsepersonell som jobber med personer med demens opplever mindre stress i vanskelig stellesituasjoner, samt økt trygghet og evne til samarbeid.

\section{Mer om forfatterne:}

Anette Hansen er spesialsykepleier i aldring, eldreomsorg og demens, med master i klinisk helsearbeid ved Høgskolen i Buskerud, avd. for Helsefag. Siri Ytrehuset er professor ved Høgskolen i Buskerud, avd. for Helsefag Kontakt: anette.hansenanotteroy.kommune.no 
ventning (self-efficacy) påvirker tanker, motivasjon og strategier og er viktige faktorer som forklarer hvor mye kraft individer bruker på ulike aktiviteter og gjøremål (11). Mestringsteorier har blant annet vært opptatt av hvordan styrke mestring for å unngå «utbrenthet» og «stress» hos helsepersonell. Usikkerhet og redsel kan påvirke evnen til å mobilisere og anvende ressurser, føre til stress og utbrenthet og dermed bli utslagsgivende for mestring (10).

Både faktorer ved individet, omgivelsene og samspillet mellom disse kan påvirke individets forventninger og opplevelsen av mestring. Individer må ha tro på og forventninger til egen mestring og denne troen kan påvirkes av andres støtte og involvering (11).

Teorier om veiledning legger nettopp vekt på at det er mulig å påvirke opplevelse av mestring (12). Begrepet veiledning brukes i mange ulike sammenhenger og er ikke entydig definert (13). En definisjon er: «Veiledning er en systematisk faglig og personlig læringsprosess hvor kunnskap, erfaring, visdom og klokhet er hjelpemidler til reflektert erkjennelse» (14, s. 22).

Innen demensforskningen relateres tidspress og håndtering av voldelige pasienter til mestring og opplevelse av stress (15). En studie som undersøkte personalets håndtering av atferdssymptomer hos personer med demens, viste at utdanning og veiledning ikke hadde innvirkning på personalets utbrenthetsnivå, men at de ansattes holdninger til å jobbe med personer med demens ble endret (16). Andre studier viser at sykepleiefaglig veiledning øker opplevelse av mestring $(17,18)$. Systematisk klinisk veiledning kombinert med individuell pasientomsorg kan minske personalets utbrenthet og belastning i tillegg til at jobbtilfredsheten kan øke (19).

Teorier om mestring skiller mellom opplevd mestring, forventet mestring og faktisk mestring. Faktisk eller reell mestring kan observeres av andre, mens opplevd mestring henspiller på personens egne vurderinger og opplevelser. Denne studien har fokus på opplevd mestring.

\section{Marte meo-veiledning}

MM er en veiledningsmetode med fokus på samspill mellom personer. Metoden blir brukt innenfor en rekke felt, både nasjonalt og internasjonalt (20). Veiledningsmetoden har sitt utspring fra Maria Aarts som introduserte metoden for å studere samspill mellom foreldre og barn (20). MM stammer fra det latinske «mars martis» som oversettes med «av egen kraft». Det sentrale fokus er å oppmuntre mennesker til ved egen kraft å fremme og stimulere utviklingsprosesser. Synet som ligger til grunn for metoden er at alle mennesker har potensial til å inngå $\mathrm{i}$ et samspill. Vi innehar flere ressurser enn hva vår umiddelbare bevissthet frembringer. Ved å bli bevisstgjort disse ressursene kan man ta de i bruk og utvikle de. Denne «oppdagelsen» foregår i samspill med andre (21).

MM bygger på videoopptak fra samhandlingssituasjoner mellom pasient og pleier. Veileder analyserer filmen og gir veiledning på utvalgte filmsekvenser. Den ansatte som ble filmet får sammen med personalgruppen tilbakemelding om sine evner til å skape kontakt og være i dialog. Veileder ser etter samhandlingsfaktorer som er utviklingsstøttende, det er det positive i samspillet som vektlegges. Det den enkelte har av kunnskap og forståelse utvikles for enda bedre å kunne øke det positive i samspillet (29). Det personalet ikke mestrer er ikke i fokus (22). Veileder og personalet skal se etter ressurser både hos personalet og pasienten. Når MM de senere år har blitt en veiledningsform innen demensomsorgen har fokuset blitt rettet mot «funksjonsstøttende prosesser» (21).

Metoden har ingen spesifikk teoretisk forankring. Aarts vektla ikke dette (20). Idealet var at metoden skulle være enkel og tilgjengelig for alle (21). Enkelte fagpersoner har i ettertid gitt metoden en teoretisk referanseramme, i tråd med praksis og erfaring hentet fra blant annet spedbarnsforskning (23).

Bakgrunnen for at veiledningen ble igangsatt ved de avdelingene som denne studien omhandler, var at personalet opplevde det som vanskelig å hjelpe enkelte av pasientene med blant annet personlig hygiene. Det var prøvd ulike tiltak og pleierne måtte ofte være to for å få stelt enkelte pasienter. Personalet opplevde stellesituasjonen som vanskelig både for pasienten og dem selv. Veiledningen ble gjennomført to ganger, med ekstern MM-veileder (terapeut). Veileder filmet en pleier i morgenstellet, analyserte filmen, plukket ut filmsekvenser og veiledet personalgruppen på bakgrunn av dette.

Hensikten med denne artikkelen er å formidle hvilken betydning deltakelse i MM har for personalets opplevelse av mestring i vanskelige stellesituasjoner. Artikkelen baserer seg på intervjuer med persona- 
let som arbeider på avdelinger hvor MM har vært gjennomført. Artikkelen vil belyse følgende problemstillinger: Hvordan opplever deltakere verdien av MM med tanke på gjennomføring av vanskelige stellsituasjoner? Og hvordan opplever deltakerne at MM har betydning for mestring i disse situasjonene?

\section{METODE}

\section{Datainnsamling}

Fokusgruppeintervju ble benyttet som datainnsamlingsmetode. I fokusgruppene fremkommer dataene i gruppediskusjon hvor deltakerne diskuterer og reflekterer sammen $(25,26,27)$. Med tanke på å skulle studere de ansattes erfaringer og vurderinger av MM er det rimelig å anta at fokusgruppens dynamikk og interaksjon i større grad enn individuelle intervjuer er formålstjenlig. Metoden er særlig egnet til å skape diskusjon i gruppe og få frem synspunkter og vurderinger som ikke ville ha fremkommet ved individuelle intervjuer $(25,26)$. Anette Hansen gjennomførte intervjuene.

Fokusgruppeintervjuene var delvis strukturerte. Intervjuguide med «åpne» spørsmål ble benyttet. I intervjuet ble det blant annet stilt spørsmål om gjennomføringen av MM, vurdering av veiledningen i forhold til vanskelige stellesituasjoner, opplevelsen av mestring og stress og vurdering av MM opp mot annen veiledning. Det ble avholdt et fokusgruppeintervju på halvannen time ved hvert av de to sykehjemmene. Intervjuene foregikk cirka et år etter at veiledningen var gjennomført. Artikkelforfatterne har selv ingen erfaring med bruk av MM.

\section{Utvalg}

Invitasjon til deltakelse i fokus-

gruppene gikk til personale på to sykehjem som hadde gjennomført MM. Sykehjemmene var beliggende i to ulike kommuner. Forskerne ønsket fem deltakere fra hvert sykehjem. Det var flere som meldte interesse og de fem første fra hvert sykehjem ble inkludert. Fra det ene sykehjemmet deltok informanter som jobbet på en avdeling med 20 pasienter. Dette var en «blandingsavdeling», med eldre som hadde somatiske sykdommer, psykiatrisk lidelse eller demens. Fra det andre sykehjemmet deltok fire informanter fra to skjermede enheter (SE) bestående av til sammen 15 personer med demens. (SE skal ha et lite, oversiktlig fysisk miljø, få beboere og et stabilt personale med nødvendig kompetanse) (1). Alle

\section{Ekstra utfordrende for ansatte kan det være når reaksjonene fra pasienten er negative eller voldsomme.}

deltakerne herfra var sykepleiere og hadde tidligere gjennomgått ulike veilednings- og kompetansehevende tiltak i tillegg til MM.

Fra «blandingsavdelingen» besto informantene av hjelpepleiere. Hos hjelpepleierne var det stort sprik i hva den enkelte hadde fătt av informasjon om metoden og mulighet for deltakelse. Hjelpepleierne hadde ikke deltatt på annen veiledning enn MM.

Informantene var fra tjue til seksti år. Noen var nyutdannet og nyansatt mens andre hadde mange års erfaring fra demensomsorgen. Sykepleierne hadde gjennomfort noe mer MM enn hjelpepleierne. I utgangspunktet skulle fokusgruppene være arbeidsstedsrelaterte og ikke fagspesifikke. Det viste seg at gruppene i realiteten også ble fagspesifikke.

\section{Analyse}

Intervjuene ble tatt opp på bånd og ordrett transkribert. Systematisk tekstkondensering ble anvendt i analysen $(28,24)$. Gjennomlesing av det transkriberte materialet identifiserte en rekke temaer. Meningsbærende enheter (tekstbiter som var sentrale elementer fra temaene som utpekte seg) ble kategorisert og innholdet kondensert til kortere og konsise formuleringer. Disse meningsbærende enhetene ble skrevet ned i en matrise inndelt i 16 kategorier. Etter videre gjennomarbeid ble noen kategorier som omhandlet ulike sider av samme tema slått sammen, eksempelvis ble "grunn til del- takelse» og «informasjon» slått sammen. Dette ga en matrise med ti temaer som igjen la grunnlaget for det som til slutt ga tre hovedkategorier: «Filmveiledningen - ga ny forståelse av vanskelige stellesituasjoner», «økt samarbeid og trygghet blant personalet» og «innvirkning på stress» (28).

Under hele prosessen ble de opprinnelige intervjuene trukket frem for å ivareta helheten. Målet var ikke å teste forhåndsantakelser, men å ta utgangspunkt i teksten og så analysere stegvis fram ny forståelse, både basert på den helhetlige analysen og de meningsbærende enhetene.

\section{Etiske hensyn}

Studien ble meldt til Norsk sam- 
funnsvitenskapelig datatjeneste (NSD). Rekrutteringen foregikk via avdelingslederne. Informantene hadde på forhånd mottatt informasjonsskriv med beskrivelse av studien. Informantene fikk informasjon om at deltakelse var frivillig og at de når som helst kunne trekke seg, uten å oppgi grunn. Dataene ble anonymisert og behandlet konfidensielt.

\section{RESULTAT}

\section{Filmveiledningen}

Felles for alle informantene var at de mente filmveiledningen hadde medført styrket oppmerksomhet $\mathrm{i}$ forhold til egen rolle i samhandling med pasienten. Ved å se filmen opplevde de å stå utenfor og se samhandlingen med andre øyne. Det gjorde at de så signaler, både fra pasienten og seg selv, som de ikke hadde registrert i selve situasjonen. Etter deltakelsen opplevde de at de evnet å se hva som kunne ha foranlediget pasientens reaksjoner. De fikk en bedre forståelse av pasientens reaksjonsmønster og dette førte til at informantene opplevde en positiv mestring. En fortalte at hun ofte tidligere opplevde at pasientens utagering kom som lyn fra klar himmel, men at filmen viste at det kunne være faktorer i situasjonen som hadde ført til atferden. Flere mente de så tydeligere at det ikke var dem personlig pasienten ønsket a «ta». En annen av deltakerne sa at hun ofte var engstelig og derfor ikke oppfattet situasjonen, men at filmen hjalp henne å «se» situasjonen. Hun fikk et bedre overblikk.

Det at filmen ga et blikk utenifra, som økte oppmerksomheten på signaler fra pasienten, mente de bidro til at de fikk et mer realistisk forhold til mulig- hetene. Veiledningen kunne derfor bidra til endring i oppfatning om hva som var en vellykket samhandling med pasientene og endre kriteriene for vurdering av egen mestring. For flere hadde veiledningen bidratt til at de nå la vekt på selve samspillet med pasienten når de skulle vurdere egen innsats, og ikke bare tilbakemeldinger fra pasientene. Et godt samspill ga positiv mestringsfølelse. Særlig ga det å kunne «stå i situasjonene» uten å øke pasientens motstand en positiv følelse. Dette gjaldt imidlertid ikke alle. Enkelte mente at pasienten måtte vise en eller annen form for tilfredshet (smil, skryt til personalet eller lignende) for at de skulle oppleve positiv mestring.

Flere av sykepleierne mente filmen ga noe utover tidligere veiledning. Filmen var et tydeligere og sterkere virkemiddel. Det var særlig den økte bevisstheten på situasjonen og på foranledninger for uheldige reaksjoner hos pasientene som metoden bidro til oppmerksomhet rundt. Enkelte mente denne metoden nettopp derfor førte til mindre bruk av tvang.

\section{Økt samarbeid}

Veiledningen førte også til økt trygghet og fellesskapsfølelse blant personalet. Flere mente at det visuelle aspektet og blikket utenifra, bidro til økt fellesskapsfølelse og refleksjon de ansatte imellom, også etter endt veiledning. Deltakerne var sammen om å se filmen og denne felles erfaringen tok de med seg videre. En av deltakerne forklarte: "Når man har sett det på film har man filmen inne i seg og spiller den av på ny». Støtten og samhandlingen økte mellom personalet og resulterte i mer bevisst nytte av å dele erfarin- ger. En av informantene sa det slik: «MM fører til at vi lærer noe av hverandre under veiledningen og henter ideer. Vi står mer sammen».

En medvirkende årsak til fellesskapsfølelsen så ut til å være måten tilbakemeldingene ble gitt på. Informantene fortalte at før de deltok opplevde de det å skulle bli filmet som skremmende. I utgangspunktet ønsket ingen å bli filmet i vanskelige stellesituasjoner, selv om de følte stort behov for veiledning på dette området. Denne holdningen endret seg og etter hvert opplevde de filmingen som uproblematisk. Det var vesentlig at veileder vektla det positive $\mathrm{i}$ samhandlingen. De ga uttrykk for at de opplevde positiv mestring når de fikk «ros». De tape ikke ansikt overfor kollegene, fordi negative tilbakemeldinger ikke var i fokus. At veileder vektla det positive førte til trygghet i personalgruppa.

\section{Innvirkning på stress}

Flere informanter formidlet at veiledningen kunne bidra til $ø \mathrm{kt}$ bevissthet over egen atferd i situasjonen. Dette førte til at de klarte å møte pasienten på en roligere og mer gjennomtenkt måte. De opplevde at deres ro smittet over på pasienten og pasienten ble roligere i situasjonen. Flere opplevde redusert stress ved at de følte positiv mestring i samhandlingen. De følte egen innsats som mer vellykket, de fikk til mer. Dette var felles for begge gruppene. En av informantene uttrykte: «Hvis ikke veiledningen hjalp konkret i situasjonen tok jeg det med meg og reflekterte over situasjonen for å finne løsninger og andre tilnærmingsmåter, det hadde jeg ikke gjort før, da hadde jeg bare gått på». 
Sykepleierne hadde før deltakelsen i MM lagt stor vekt på opplæring og annen veiledning. De opplevde i tillegg mindre tidspress i hverdagen enn hjelpepleierne. Sykepleierne mente MM bidro til positiv mestringsfølelse og dermed redusert stress i vanskelige stellesituasjoner. De opplevde at MM hadde positiv innvirkning på stress i seg selv, men flere poengterte betydningen av å kombinere den med økt fagkunnskap.

Hjelpepleierne mente at knapphet på tid var den største stressfaktoren. Når de deltok på $\mathrm{MM}$ hadde de opplevd økt positiv mestring. Noen mente at veiledningen kunne redusere opplevelsen av stress som hadde med tidspress å gjøre fordi den viste dem alternative måter å møte pasienten på. Dermed ble tid frigjort. Andre av hjelpepleierne mente at det var nødvendig med flere ansatte når $\mathrm{MM}$ skulle brukes. De var tvilende til om MM kunne være stressreduserende hva tidspress angikk. «Det hadde vært en drømmesituasjon hvis alle kunne jobbet etter denne metoden hele tiden. Men det har vi jo ikke tid og ressurser til, det er jo det som stopper det».

\section{DISKUSJON}

Deltakerne mente filmingen økte oppmerksomheten på signaler fra pasientene og deres egen fremtoning overfor pasienten. Flere av deltakerne sa de følte de kunne stå utenfor situasjonen og se med andre øyne hva som skjedde i stellesituasjonen. De beskrev denne opplevelsen som et «utenifrablikk». De opplevde at denne økte bevisstheten førte til positiv mestrings- og fellesskapsfølelse. Økt bevissthet og «utenifrablikket» i forhold til situasjonen, beskrives også i en studie av MM's innvirkning på samspill mellom pasient og pleier (29). En annen studie av MM og mor- barn-samspill (30) peker også i retning av at utenifrablikket skaper positiv mestring ved å gi ny forståelse og bevissthet omkring samhandlingen. Det må bemerkes at vi ikke nødvendigvis kan sette likhetstegn mellom veiledning gitt av MM-terapeut til barns foreldre og MM-terapeutens veiled-
(31). Det kan være ekstra utfordrende for ansatte kan det når reaksjonene fra pasienten er negative eller voldsomme. MM medførte at flere ansatte vektla andre signaler enn smil og skryt fra pasienten som bedømmingsgrunnlag for eget arbeid. Selve samhandlingssituasjonen og hvordan denne forløp ble gjenstand for vurdering og refleksjon. Deltakerne fikk ikke bare en bedre forståelse for selve

\section{$\int$ Veileder skal framheve de positive samhandlingssituasjonene og gi positive tilbakemeldinger.}

ning til utdannet helsepersonell i demensomsorgen.

I vår studie mente deltakerne at MM kunne bidra til reduksjon av stress i vanskelige stellesituasjoner. Økt bevissthet, refleksjon, mestring og fellesskapsfølelse kan fremheves som en målsetting for veiledning generelt (12). MM som visuell veiledning kan kanskje forebygge vanskelige stellesituasjoner ved at personalet reflekterer sammen og benytter sin kunnskap om pasientens og egne reaksjoner. Det ser videre ut til at økt oppmerksomhet kan bedre tryggheten i samspillsituasjonen, og derigjennom fremme bruken av hensiktsmessige mestringsstrategier. Personalgruppa blir tryggere på hverandre, noe som igjen kan gi økt mestringsopplevelse (10).

Denne studien viser at MM kan bidra til opplevelse av økt positiv mestring, også fordi deltakelse kan påvirke ansattes bedømming av egen innsats. Personer med demens kan ha redusert evne til å gi tilbakemeldinger i tråd med sosiale og kulturelle forventninger samhandlingssituasjonen, men også et bredere repertoar for bedømming av egen innsats og en mer realistisk vurdering av egen mestring i vanskelige stellesituasjoner.

Vi så innledningsvis at studier i demensomsorgen peker på faktorer som kan medføre en belastende arbeidssituasjon. Testads studie (32) viser at stress og belastning i direkte pasientkontakt, ikke var så fremtredende som antatt, men at det derimot var andre forhold på arbeidsplassen som påvirket negativt. Deltakerne i vår studie hadde ulik fagbakgrunn og kom fra ulike avdelinger. Sykepleierne hadde annen veiledningserfaring og vurderte MM i forhold til denne. De var mer spesifikke på hvilket utbytte veiledningen ga. Intervjuet med hjelpepleierne handlet mer om tidsressurser og travehelt, og rollen MM kunne spille i den sammenhengen. Ikke alle hjelpepleierne var enige $i$ at MM kunne redusere tidspress. En norsk studie viser til at helsepersonell opplever ressursmangelen som en stor belastning (33). Andre av hjelpepleierne 
mente at MM ga alternative handlingsvalg og derigjennom kunne redusere tidspresset. Resultatene gir grunn til å peke på - på lik linje med andre (7) at mer tid i seg selv ikke trenger å være tilstrekkelig. Økte ressurser og veiledning bør kombineres.

Sykepleierne la liten vekt på tidspressproblematikken. Om dette er fordi SE er små og oversiktlige enheter med mer ressurser og en mer ensartet pasientgruppe, er vanskelig å si. Det kan også være at personalet har annen kompetanse og mer fokus på veiledning. Dette kan imidlertid være faktorer av betydning $(1,35)$.

Studien artikkelen bygger på har hatt fokus på ansattes opplevelse av MM og hvordan veiledningen har påvirket opplevelsen av mestring. De ansatte la vekt på at metoden har gitt bedre forståelse for hendelsesforløpet. Varhet for egne og pasientenes reaksjoner og foranledningene til disse har også $ø$ kt. Videofilmingen gjør at situasjonen kan inndeles i mindre hendelser. Ansatte kan kjenne igjen handlinger som gir positive reaksjoner hos pasienten og dermed forstå hvordan de best når frem med hjelp. Et bærende prinsipp ved metoden er at veileder skal framheve de positive samhandlingssituasjonene og gi positive tilbakemeldinger. Christensen (21) hevder at det å unngå fokus på negative sider ved relasjonen til pasienten, er en av styrkene ved MM. Denne tilnærmingen kan bidra til positiv mestringsfølelse. Men vi kan stille spørsmål om det å bare vektlegge positiv samhandling kan føre til at dysfunksjonelle aspekter i stellesituasjonen blir videreført siden de blir oversett. Vi kan videre stille spørsmål om metoden kan føre til at det blir mindre aksept for å ta opp problemer i stellesituasjonen hvor personalet føler redusert mestring? Dette er svært relevante spørsmål. I andre sammenhenger er det pekt på at det er behov for tilbakemeldinger og veiledning også på feil og uheldig praksis (34). Feil og en uheldig praksis, som står $\mathrm{i}$ motsetning til faglige standarder og ivaretakelse av pasientenes behov, kan være rotfestet $i$ en avdeling. Dette kan være vanskelig å endre uten at denne praksisen gis spesiell oppmerksomhet.

\section{Begrensninger}

Deltakerne var i all hovedsak positive til MM. Deltakelse var basert på selvseleksjon. Vi kan ikke se bort fra at de av personalet som sa ja til å delta var særlig positivt innstilt og ønsket å videreformidle dette. Studien viser positive virkninger av MM, men det er grunn til å stille spørsmål om det var den ekstra oppmerksomheten som bidro til dette. Videre kan man også tenke at de positive tilbakemeldingene deltakerne fikk i veiledningen var med på å farge deres oppfatning av metoden. Ville andre veiledningsmetoder og/eller mer tid gitt samme resultat?

Rekruttering foregikk via avdelingsledere ved institusjonene. Det var ikke avdelingen som skulle vurderes, men bruken av MM. Det er likevel mulig at deltakerne var forsiktige med negativ kritikk. Intervjuene tydet imidlertid ikke på dette. Deltakerne fortalte åpnet om erfaringer med veiledningen.

Noen av informantene jobbet på samme arbeidsplass som artikkelforfatteren som gjennomførte fokusgruppeintervju- ene. Hun arbeider ikke direkte sammen med pleiepersonalet, men dette kan ha innvirkning på hva de ønsket å vektlegge i intervjuet (28). Det kan ha ført til at informantene har holdt tilbake erfaringer. Forskerens inntrykk var imidlertid at deres kjennskap til henne var positivt for studien. At de kjente til henne kan ha bidratt til å skape en trygghetsfølelse og dermed gjøre det lettere å dele sine opplevelser.

\section{KONKLUSJON}

Denne studien viser at MM kan ha positiv innvirkning på opplevelse av mestring i vanskelige stellesituasjoner. Opplevelsen av positiv mestring økte på bakgrunn av forhøyet bevissthet, økt trygghet og evne til samarbeid. Videre antyder resultatene at metoden kan bidra til senket stress i vanskelige situasjoner. Derimot er det mer usikkert om veiledningen kan føre til spart tid ved at de ansatte jobber på en annen måte.

\section{IMPLIKASJONER FOR PRAKSIS}

MM kan være en verdifull metode. Det er samtidig viktig å huske på at MM ikke vil dekke alle veilednings- og kompetanseutviklingsbehov. Metoden må kombineres med veiledning og kunnskapsoppbygging om sykdommen, pasientens behov, holdningsarbeid og kunnskap om hva som er nødvendig kvalitet i omsorgen. Hvert arbeidssted bør vurdere eget behov for veiledning og kompetanseoppbygging for å kunne tilpasse metoder og tilnærminger. MM kan være en nyttig metode ved særskilte samspillsutfordringer.

\section{VIDERE FORSKNING}

Det er behov for flere kvalitative 
studier av metoden blant andre grupper for å få et bredere kunnskapsgrunnlag for vurde- ring av metoden. Med tanke på framskaffelse av kunnskap om metodens muligheter og begrensninger, er det viktig å studere ansatte både med positive og negative erfaringer.

\section{REFERANSER}

Sosial- og helsedirektoratet,0slo 2007. Glemsk, men ikke glemt - Om dagens situasjon og fremtidas utfordringer for å styrke tjenestetilbudet til personer med demens.

Engedal K, Haugen PK. Lærebok demens - fakta og utfordringer. Nasjonaltkompetansesenter for aldersdemens, Sem. 2004.

Selbæk G. Atferdsforstyrrelser og psykologiske symptomer ved demens. 2005. Tilgjengelig fra: http://www. tidsskriftet.no/index.php?seks $i d=1200402$. (Nedlastet 10.05.2008)

Hatløy I, Alnes RE. Positivt samspell i demensomsorga: Har rettleiing med Marte Meo-metoden effekt? Tidsskrift for norsk psykologforening. 2007:44:1363-1371.

Ballard C, Corbett A, Chitramohan $\mathrm{R}$, Aarsland D. Management of agitation and aggression associated with Alzheimer's disease: controversies and possible solutions. Current opinion in psychiatry. 2009;22:532-540.

Rokstad AMM. Kommunikasjon på kollisjonskurs - Når atferd blir vanskelig å mestre. Forlaget aldring og helse, Tønsberg. 2005.

Kirkevold $\emptyset$. Bare vi hadde flere pleiere ... I: Kruger R.M.E. (red). Evige utfordringer. Forlaget aldring og helse. Tønsberg. 2006.

Brooker D. Dementia Care Mapping: A review of the research literature. The gerontologist, Washington. 2005;45:1119

Hyldmo I, Nordhus IH, Hafstad R. Marte Meo: En veiledningsmetode anvendt i demensomsorgen. Tidsskrift for norsk psykologforening. 2004:41:16-20.

Lazarus RS, Folkman S. Stress, appraisal, and coping. Springer publishing company, New York. 1984.

Bandura A. Self-efficacy: the exercise of control. W.H. Freeman, New York. 1997.

Tveiten S. Veiledning - mer enn ord. Fagbokforlaget, Bergen. 2008.

Skagen K. Det historiske tilbakeblikket.
I: Skagen K. (red). Kunnskap og handling i pedagogisk veiledning. Fagbokforlaget, Bergen. 2000

Teslo AL. Mangfold i faglig veiledning - for helse- og sosialarbeidere. Universitetsforlaget, Oslo. 2006

Edwards D, Burnard P, Coyle D, Fothergill A, Hannigan B. Stress and burnout in community mental health nursing a review of the literature. Journal of psychiatric and mental health nursing. 2000:7: 7-14.

Visser SM, Mccabe MP, Hudgson C, Buchanan G, Davison TE, George K. Managing behavioural symptoms of dementia: Effectiveness of staff education and peer support. Aging \& mental health. 2008;12:47-55.

Naper $\emptyset$, Hoffart RA. Veiledning avgjørende for trivsel og mestring. 2000. Tilgjengelig fra: http://www. sykepleien.no/article.php?article $\mathrm{D}=482$ \& categoryI $\mathrm{D}=61$. (Nedlastet 04.05.2008).

Begat I, Ellefsen B, Severinsson E. Nurse's satisfaction with their work environment and the outcomes of clinical nursing supervision on nurse's experiences of well-being - a Norwegian study. Journal of nursing management. 2005:13:221-230.

Brodaty H, Draper B, Low LF. Nursing home staff attitudes towards residents with dementia: Strain and satisfaction with work. Journal of advanced nursing. 2003:44: 583-590.

Aarts M. Marte Meo grundbok. Aarts productions, Holland. 2005

Christensen SS. Marte Meo-metoden arbejdet med ældre. Klinisk sygepleje. 2004:18:65-73.

Andersen A.E. Metoden som kan forandre praksis - En grounded theory studie av Marte Meo terapeuter i demensomsorgen. Master of public health, (upublisert materiale). Nordiska hogskolan for folkhalsovetenskap i Gøteborg, Gøteborg. 2009

Lund K. Vurdering av Marte Meo-metoden i lys av relevant teori og forskning. Det utdanningsvitenskapelige fakultet pedagogisk forskningsinstitutt, lupublisert materiale). Universitetet i Oslo, Oslo. 2001.

Kvale S. Det kvalitative forskningsintervju. Gyldendal Akademiske, Oslo. 2001. Morgan DL. The focus group guidebook. Saga publications, London. 1998.

Wibeck V. Fokusgrupper; Om fokuserande gruppintervjuer som undersøkningsmetod. Studentlitteratur, Lund. 2000.

Lerdal A, Karlsson B. Bruk av fokusgruppeintervju. Sykepleien forskning. 2008:3:172-175.

Malterud K. Kvalitative metoder i medisinsk forskning. Universitetsforlaget, Oslo. 2003.

Alnes AE, Hatløy I. Marte Meo-veiledning i skjermet avdeling - Utdrag fra prosjektet samspell med aldersdemente. Demens og alderspsykiatri. 2008:12:29-31.

Vik K, Hafting M. Video interaction guidance offered to mothers with postnatal depression: Experiences from a pilot study. Nordic journal of psychiatry. 2006:60:234-138

Mitty E, Flores S. Assisted living nursing practice: the language of dementia: theories and interventions. Geriatric nursing. 2007;28(5):283-288

Testad I. Agitation and use of restraint in nursing home residents with dementia - prevalence, correlates and effects of care staff training. (doktoravhandling). Universitetet i Bergen, Bergen. 2010.

Førde R, Pedersen R, Nortvedt P, Aasland OG. Får eldreomsorgen nok ressurser? 2006. Tilgjengelig fra: http://www.tidsskriftet.no/lts-pdf/ pdf2006/1913-6.pdf. (10.09.2008).

Bjørk IT. Practical skill development in new nurses. Nursing Inquiry 1999;6:3447.

Engedal K, Kirkevold $\emptyset$, Eek A, Nygård AM. Makt og avmakt - Rettighetsbegrensninger og bruk av tvangstiltak i institusjoner og boliger for eldre. Nasjonalt kompetansesenter for aldersdemens, Sem. 2002 